\title{
GEOGRAPHY UNIVERSITY STUDENTS' AWARENESS OF THEIR OWN LEARNING PROCESS DURING THE 2013 NEUBRANDENBURG INTERNATIONAL SUMMER SCHOOL
}

\author{
Oana-Ramona ILOVAN \\ Babeş-Bolyai University, Faculty of Geography, Cluj-Napoca, Romania \\ e-mail: ilovanoana@geografie.ubbcluj.ro \\ HAVADI-NAGY Kinga Xénia \\ Babeş-Bolyai University, Faculty of Geography, Cluj-Napoca, Romania \\ e-mail: xenia.havadi@geografie.ubbcluj.ro
}

(Received: September 2015; in revised form: December 2015)

\begin{abstract}
We presented research on Romanian students' educational process during an international interdisciplinary summer school that took place in 2013, in northern Germany, focusing on regions in transition. We questioned our 12 Romanian students about their expectations and needs of formation related to the summer school activities and we received their answers in the form of learning journals as part of their portfolios. We presented the results of our research as an answer to the question on the efficiency and benefit that summer school activities could bring to Geography university students' education and we concluded that learning journals were efficient educational tools.
\end{abstract}

Keywords: learning journal, portfolio, university education, feedback, learning awareness and empowerment 


\section{INTRODUCTION}

We presented the recent research we realised on Romanian students' educational process during an international (5 countries) interdisciplinary summer school. This took place during 2 weeks in September 2013, in Neubrandenburg and Lassan, Germany, and it focused on Shaping Regions in Transition: Small Town and Rural Development Challenged by SocioDemographic Change. This activity included lectures, excursions, discussions, working groups on topics, and presentations. Both authors of this paper were co-organisers of the summer school in Germany.

Our research had two aims. The first one was to encourage and enable our 12 students to engage in their learning process during the summer school. The second was to do an exploratory research of their learning process that could help us improve future similar activities (i.e. geography university summer schools).

Before the beginning of the activities, we asked students to shortly assess their strengths and weaknesses as related to the offer of the educational programme (the summer school) and to list the competences they wanted to develop both as geographers (subject-specific competences) and as EU citizens (observing the EU recommendations for the development of the eight key-competences necessary in a process of lifelong learning and useful in order to get a job).

In addition, we questioned our 12 Romanian students (MSc and BSc levels) about their expectations and needs of formation, taking into account the following: the learning activities the programme proposed, the teaching methods, the products they realised as proof that their initial objectives and targets were accomplished. Students put together portfolios and completed learning journals as a part of these. Their answers included information about what and how they learnt and how they felt during this process.

In this context, we discussed students' motivation and willingness to co-operate reflected in their learning journals. We presented the results of our research as an answer to the question on the efficiency and added value that summer school activities and learning journal writing could bring to geography university students' education. 


\section{THEORETICAL SUBSTANTIATION}

Due to the fact that the framework of our research focused on two main correlated ideas: the relevance of summer schools for university geographical education and the efficiency of learning journals for fostering learning in such a context, we presented a theoretical background on the key competences that can be developed during a summer school and on journal writing in education.

On the key competences that can be developed during a summer school

In the European Union, the European Parliament and the Council (Recommendation 2006/962/EC, 2006; Brochure: Key Competences for Lifelong Learning - European Reference Framework, 2006; A Summary of EU Legislation Establishing the European Framework of Key Competences) defined eight key competences necessary for personal development, fulfilment, and for lifelong learning.

University students and professors participating at summer schools may develop a series of key competences (cf. A Summary of EU Legislation Establishing the European Framework of Key Competences):

- communication in foreign languages (facilitating intercultural understanding);

- basic competences in science (how to use and apply scientific knowledge and methodologies and thus understand the changes caused by human activity and be aware of their responsibility as citizens);

- learning to learn (ability to pursue and organise their own learning, while being aware of learning methods and opportunities);

- social and civic competences (personal, interpersonal and intercultural competences, understanding codes of conduct and customs in diverse contexts; awareness of the meaning and enacting of democracy, justice, equality, citizenship and civil rights enabling active and democratic participation);

- sense of initiative and entrepreneurship (promoting good governance due to the ability to turn ideas into action using creativity, innovation and the ability to plan and manage projects focusing on realistic objectives, to seize opportunities and to be aware of and observe ethical values).

These key competences provide a reference framework for university students' education and success in adult and working life and are promoted during summer schools activities because of the efficient combination between theory and field work in an international, partly guided interdisciplinary working environment. 


\section{On journal writing in education}

We briefly reviewed the studies on journal writing in the educational context. There is relevant research on the role of journal writing for enhancing student learning in higher education (Charlesworth and Foster, 1996; Cook, 2000; Haigh, 2001; Hyers, 2001; Langer, 2002; McCrindle and Christensen, 1995; Morrison, 1996; O’Rourke, 1998; Park, 2003; Thorpe, 2004; Wagner, 1999), for lifelong learning (Carroll, 1994; Walden, 1988), during field trips (Stanesco, 1991) and as an effective educational tool fostering reflective learning in Earth sciences and in general (Cantrell, Fusaro and Dougherty, 2000; Connor-Greene, 2000; Croxton and Berger, 2001; Dart et al., 1998; Fouberg, 2000; Hedlund, Furst and Foley, 1989; Sublett, 1991; Yinger, 1985).

In his research, Park (2003) proved that "the learning journal has good potential to increase student interest in and engagement with course material, to encourage and empower students to take more responsibility for their own learning, to be more reflective in their study, and to allow them to have a voice and provide valuable feedback to the teacher" ( $p$. 183). Moreover, he argued that active learning was a good starting point for engaging his students in writing learning journals: "Students who actively engage with what they are studying tend to understand more, learn more, remember more, enjoy it more and be more able to appreciate the relevance of what they have learned, than students who passively receive what we teach them" (Park, 2003, p. 183).

Similarly, Morrison (1996) showed that learning journals were significant for the development of reflective practice on the students' personal, academic, professional and evaluative development in higher education and for their empowerment.

In addition, Thorpe (2004) argued that learning journals provided practice that was reflective rather than routine and was able to categorise students into "nonreflectors (i.e., lack evidence of deliberate appraisal), reflectors (i.e., demonstrate insight through analysis, discrimination, and evaluation), and critical reflectors (i.e., indicate a transformation from initial perspective)" (p. 327).

McCrindle and Christensen (1995) used an experimental group that developed a written record of their learning processes and showed that the university students in that group employed "more metacognitive strategies and more sophisticated cognitive strategies during a learning task" ( $p .167)$. In addition, those students were characterised by greater awareness of their learning process and the cognitive strategies that they used and had generally more sophisticated conceptions of learning (McCrindle and Christensen, 1995). 


\section{FRAMEWORK OF THE RESEARCH - ERASMUS INTENSIVE PROGRAMS (IPS) (Havadi-Nagy and Ilovan, 2013)}

ERASMUS ${ }^{1}$ offers Intensive programs (IP) for the development of students' and professors' professional and intercultural competences.

An IP is a compact study program of two to six weeks. It may be a summer school or a block seminar. A project coordinator which is a European university plans the program along with at least two other ERASMUS partner universities in two different countries. The IP is supported by DAAD. ${ }^{2}$ In the framework of the ERASMUS exchange, the IP is considered an innovative experimental ground for European partner universities. Particularly innovative projects with an interdisciplinary approach, having high European added value are funded (https://eu.daad.de/erasmus/management/intensivprogramme/de/11627intensivprogramme/). This IP stimulates and enables the inclusion of experts with social, administrative, and business backgrounds.

Academic achievements are recognized by all participating universities with ECTS credits.

The International Summer School at the University of Applied Sciences (UAS) - Hochschule Neubrandenburg, Germany (cf. Shaping Regions in Transition..., 2013; Programme - International Summer School..., 2013) - "Shaping regions in transition: Small town and rural development challenged by socio-demographic change" - brought together students and professors from different disciplines and European countries (Bulgaria, Germany, Finland, Poland, and Romania) to gain a common multi-perspective understanding on securing public services and community development in mostly underdeveloped rural regions within Europe, challenged by demographic change and socio-economic transformation.

This summer school took place at the University of Applied Sciences Neubrandenburg and in Lassan, a small town and communal centre in the Vorpommern-Greifswald district, in Mecklenburg-Western Pomerania, Germany, in September 2013, within the Erasmus IP. The summer school lasted for 13 days with ten working days. Romania participated with 12 students and three professors.

Professors from all countries had diverse professional backgrounds (Geography, Environmental Sciences, and Economy), being able to offer

\footnotetext{
1 A European student exchange program established in 1987, offering university students the possibility to study or work in another European country, for a period between 3 and 12 months.

2 Deutscher Akademischer Austauschdienst - The German Service for Academic Exchange.
} 
multi- and transdisciplinary perspectives. Selected students from all countries had also diverse undergraduate study backgrounds (Geography, Tourism, Cartography, Environmental Sciences, Economy, and Cultural Studies). Common research questions and knowledge needs were answered during their work with professors, regional experts and actors (from politics, economy, public administration, and from planning authorities), local decision makers and people, and with the civil society.

Students learned advanced theoretical and practical knowledge, aiming at developing transferable strategies and practical solutions which could be adapted to their home country reality. At the same time, solutions from their home country were transferred to the study area in Germany.

The teams working on selected topics were made up of participants from each partner institution and from different professional backgrounds. These international and interdisciplinary exploration teams enabled the exchange of professional perspectives and the training of transversal competences.

Participants went on trips to interesting sites to learn about the characteristic features of Eastern Mecklenburg-Western Pomerania. Those trips fostered interaction and intercultural learning. Trips within the region focused on: renewable energy; environmental protection; technical infrastructure; planning/architecture/social aspects/mobility, and nature protection/agriculture /tourism. Research trips took place in Lassan and its villages and participants learnt about best practice examples (e.g. a national park, a resort town, eco-farming, etc.).

Students also participated at lectures on general themes ("Shaping regions in transition: Small town and rural development challenged by socio-demographic change: European, regional and local perspectives" and "European Regions in Transition" - Presentations of participating countries' perspective and main thematic focus from Bulgaria, Germany, Finland, Poland, and Romania), on thematic aspects - Village development (social and cultural innovations by "Space Pioneers"); Quality of life (family-friendly and hospitable place); Sustainable tourism (infrastructure and services improvement); Regional economy (small business opportunities and local energy production); Sustainable mobility (rural transport and integrated mobility plans); Town planning (multigenerational campus); Sustainable infrastructure (supply and waste management), and Ecological land use (landscape valorisation and nature education) - and on the region ("Regional development and spatial planning in the district Mecklenburgische Seenplatte"; "European agricultural policy and its effects on regional transition in Mecklenburg-Western Pomerania"; "Nature protection and land use planning"; "Perspectives for educational institutions in small towns rural communities"; "Social cohesion and health situation in 
small towns and rural communities in Mecklenburg-Western Pomerania" lecture and workshop).

Before starting their field work, students took part in a short presentation of methods and tools for practical field work (qualitative social research, regional analysis, urban structural survey, interviewing techniques, photo documentation, etc.). Moreover, preparing for field work included establishing objectives, presentation of proposed field teams and subjects/tools, team building, subject and methodological focus, spatial orientation, identification of relevant actors, and preparing of working groups moderation. The proposed field teams focused on village development (space pioneers); social development and health; tourism; regional economy (renewable energy); mobility; town planning (Centre for Education); sustainable infrastructure; and ecological land use.

Two public workshops took place. The first one consisted of discussions and development of research questions and knowledge needs for Lassan, involving the local people into efficient participatory research projects (Breitbart, 2012). The second public workshop consisted of students' returning to the local community to present and discuss possible strategies, solutions, and ideas for Lassan. They also reflected on their learning experiences during a public workshop with citizens and decision makers from Lassan.

Organisers encouraged problem-orientated, interactive and situational learning approaches and students acquired new social skills and developed the ones they had by interacting with local people. Nonetheless, they developed their rhetorical and public presentation skills in a foreign language (German and English).

Students and professors were team partners, sharing knowledge and methods. Socializing and experiencing European cultures were possible during the intercultural evening, during the day off, and especially in the work groups and during field trips.

\section{MATERIAL AND METHOD}

The research process included three stages: before the beginning of the activities (when we communicated the task to our students and asked them to write their expectations, strengths and weaknesses related to the international summer school), during the activities (when we observed their activity) and after these (when we analysed the provided materials: learning journals and portfolios).

Before the beginning of the activities, we asked our students to write the strengths and weaknesses related to the offer of the educational programme, to list the competences they wanted to develop as geographers 
(subject-specific competences) and as citizens (EU recommendations; 8 key-competences for lifelong learning-LL).

After the activities, we received the learning journals and portfolios and we used extracts from our students' journals that they had written during the summer school and products of their group work (part of their portfolios) in order to illustrate how they viewed such an educational experience (i.e. the international summer school) and how they approached the task of writing learning journals, as those were journals written on our demand. For analysing their feedback, we took into account the literature in the field.

We asked our students to create portfolios and write learning journals as the main part of these portfolios during and after the activities, in order to identify their expectations and needs of formation, the learning activities that the programme proposed, the teaching methods facilitating their learning, the products they realised as proof that their initial objectives and targets were accomplished, and especially what and how they learnt and how they felt during this process.

The findings of our research are the result of an analysis of the learning journals and portfolios, after the activities (after the summer school ended). We did not ask our students to comment about their activity of writing learning journals, so we did not have their feedback on this, too.

\section{RESULTS AND DISCUSSION}

Students' goals, strengths and weaknesses related to the international summer school

We asked our students what were the goals they wanted to accomplish during the summer school. We grouped their answers according to five of the eight key-competences for LL:

- communication in foreign languages: to speak English and/or German;

- basic competences in science: learning new and practical information; professional development; learning/using certain work methods and techniques; discovering new things; innovative ideas;

- learning to learn: learning as much as possible; forming new work methods; group work;

- social and civic competences: relationships with future perspectives/connections with universities from abroad; getting to know new people and making new friends; understanding students' and 


\section{GEOGRAPHY UNIVERSITY STUDENTS' AWARENESS OF THEIR OWN LEARNING PROCESS DURING THE 2013 NEUBRANDENBURG ...}

professors' from the other countries culture and thinking manner; visit to Berlin; how does the German education system function? New cultures/new people/beautiful memories; result of an international co-operation;

- sense of initiative and entrepreneurship: putting certain ideas into practice; participating at finding solutions; identifying ideas appropriate for Romania; experiencing success.

As we also asked them to write what were their assets in accordance with the educational programme offered by the summer school, below we grouped their answers according to the components of competences (Brien, 1997; Dulamă, 2010). Brien (1997) considered the competence someone's capacity to realise a certain task that requires a high number of operations, while a competence is a sum of declarative knowledge (ideas), procedural knowledge (methods, strategies, techniques, procedures), and attitudes (attitudes and behaviour) that someone activates while planning and carrying out a task (Dulamă, 2010, p. 12, p. 15). Taking these into account, we were able to group our students' answers:

- theoretical/scientific knowledge: professional training in certain fields; previous knowledge; special knowledge: cartography, drawing; ideas for tourism development; German language knowledge;

- procedure/skills: practical spirit; organisational spirit; quick learning skills; experience for team work; good memory; good attention;

- attitudes: responsibility; seriousness; sociable and communicative; quick adapting to certain situations; perfectionist; optimist; involvement, interest; creativity.

For the question on what were their weaknesses in accordance with the educational programme offered by the summer school, students focused mainly on their lack of competences or on their wish to overcome weaknesses:

- communication in foreign languages: lack of practice in speaking English and especially specialised language for geography; not speaking German - perceived as a problem when obtaining data during activities;

- basic competences in science: lack of knowledge/experience in certain fields;

- learning to learn: lack of experience for group work;

- social and civic competences: expressing ideas without any constraints; not giving up when things do not work as one would like them to; shyness.

- sense of initiative and entrepreneurship: introvert personality; 


\section{Learning journals}

In this part of our paper, we discussed students' motivation and willingness to co-operate in reflecting on their learning, we realised an analysis of their learning journals and we presented some discussions related to the question on the efficiency and added value that international summer school activities could bring to Geography university students' education. Moreover, as stated in the aims of our research, we also looked for evidence that our students were more aware and reflective of their learning process while writing a learning journal.

\section{1) Formal features of the learning journals}

We analysed 12 learning journals, meaning that each participating student from Romania gave us such a journal. Most of them were for each day and on hours, the other had short presentations of each day. The number of details varied from one journal to another. Some of them focused on the aspects taken into account from the very beginning, the others underlined only one aspect. Some included drawings and sketches for a certain studied topic. Others included short descriptions and key words, while others became more superficial day by day (e.g. notes got shorter to the end in the case of Student 7). From this perspective, we could judge students' attitude towards the task (writing the learning journal), as well as each respondent student's style of work.

Students' motivation and willingness to learn was reflected in their journals that we were able to categorise. We identified two types of journals. The first type includes those learning journals that they realised: for each day and on hours, in detail, paying attention exactly to the proposed aspects, organised thorough descriptions, with drawings and sketches. The second type is that of the learning journals with short presentations of each day, less details, underlining only certain things, short descriptions, key words, and certain journals became superficial with the time passing. There were cases when students (e.g. Student 6) used only the first day the detailed structure with all the aspects they had to pay attention to during activities.

The learning journals included notes in diverse languages, notes about the general programme (e.g. the approached topics, parties, and visits) and notes on participants' feelings (e.g. fulfilled/unfulfilled personal expectations), sketches, drawings (Figure 1), notes on intercultural interaction, etc.

Although students used diverse languages to write their journals (Hungarian, Romanian, or the language of the lecture - German or English), most of them used Romanian, even if that was not their mother tongue for 


\section{GEOGRAPHY UNIVERSITY STUDENTS' AWARENESS OF THEIR OWN LEARNING PROCESS DURING THE 2013 NEUBRANDENBURG ...}

half of the students from Romania. They chose to write in Romanian because they knew that only two of their three teachers spoke Hungarian. For instance, Student 2 wrote in Romanian, in Hungarian (being a Hungarian ethnic), in German (he had studied at a German school from Romania), and in English. Similarly, Student 3 wrote that "sometimes I mix four languages". The analysis of their notes in all these four languages was possible because the co-author of this paper speaks the respective languages.

Moreover, there were situations of lost in translation information (e.g. when people presented in German and somebody translated into English) that students who spoke both German and English mentioned (in the case of Student 2, Student 9 and Student 11 or as Student 2 noticed "the day ended with a show of the group $X$ from Lassan and unfortunately those who did not speak German could not enjoy it thoroughly").

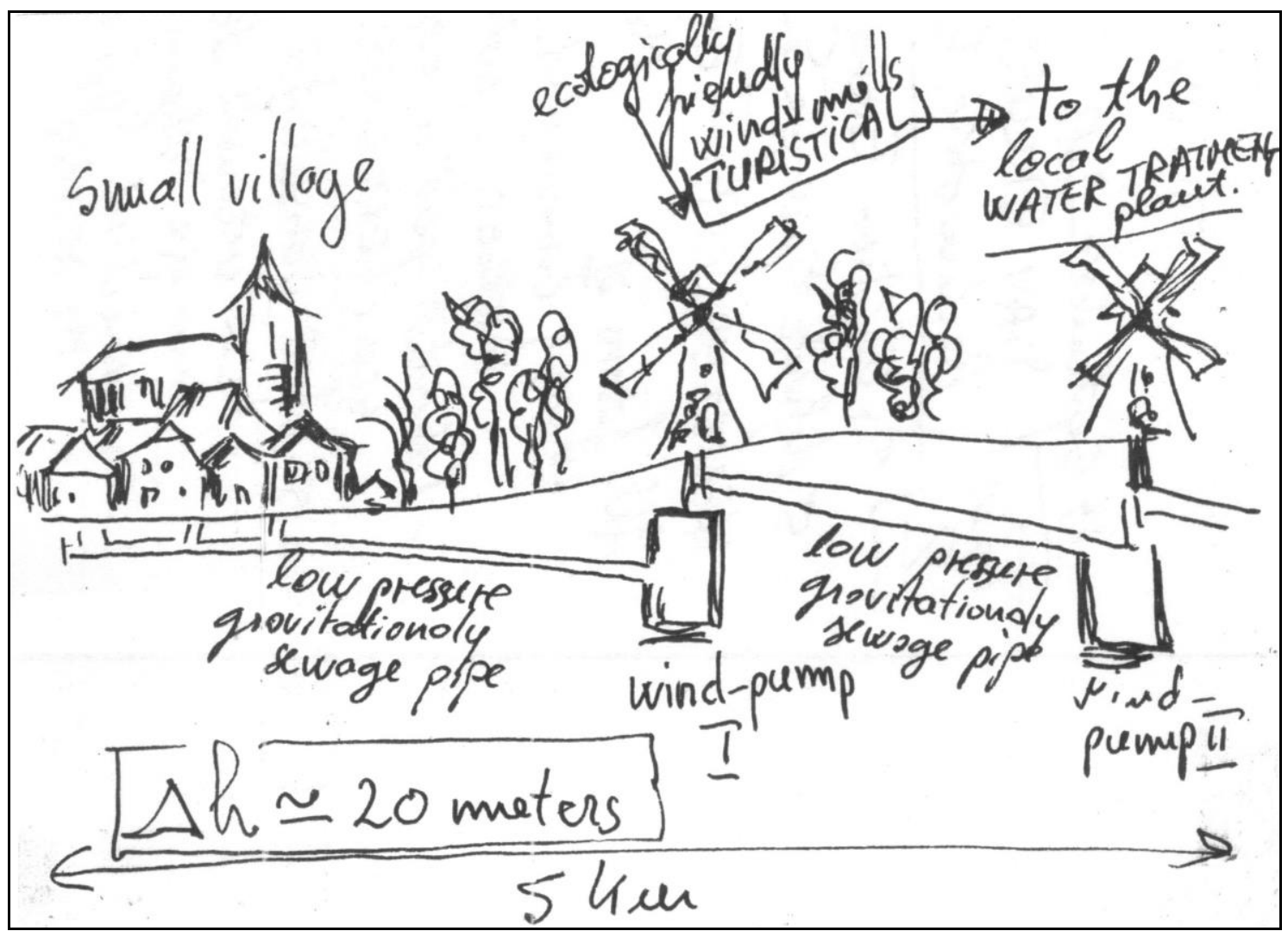

Fig. 1. Explanatory drawing realised by one of the students (author: Maroşi Zoltan)

The organising of the journal varied from one student to another. For instance, there was a journal where the student wrote its structure beforehand and it remained uncompleted where the respective structure did not fit the contents of the next days (activity, hour, how I learnt, how I felt, learning proofs, lifelong learning, connection to the labour market, ICT, 
useful contacts, assessment, satisfaction, formation needs, other observations) (Student 1). Student 2 had an incomplete journal.

Student 11 realised a coding system to enable his answer to the long series of questions they received from us, the professors, after they arrived at the summer school, before the beginning of the first activity. Our 12 students had to take into account those questions when organising their learning journals. In the case of Student 11 , he allotted a code to each question and he inserted his answers after each code, each day. Table 1, where we inserted a part of his answers (that he organised according to days and activities), shows that certain questions received more answers than others.

Table 1. Coded organising of the learning journal (Student 11)

What have I learnt today? C1
How have I learnt today? C2
How have I felt today? C2
Which methods have the professors used? C4
What proofs do I have for the realised learning process? (product of that specific
activity) D
Is my lifelong learning capacity developed? DCIV
Is there a connection between what I have learnt and what I can apply in the
future? RIV
Have I established useful contacts for the future? CUV
How am I assessed/do professors require feedback from me? F
Have my education needs been satisfied? NF
C1 - "In Germany, when a problem occurs at the community level, ordinary
people form associations and try to fix what they cannot solve individually (e.g.
population loss, lack of shops) and propose interesting ideas that they can
apply"; "My understanding of small towns changed - together with the
surrounding villages they form a region"; "To solve social problems, we need
educated people and co-operation"; "To solve problems, first one has to talk to
each other, one creates bridges between different social groups"; "The professor
noticed that people in Lassan organised themselves to make decisions for their
future; therefore he wanted to get the summer school (SS) in contact with
Lassan. The SS is international and interdisciplinary; he is not sure if the SS will
be a success"; "For development, one needs to find those local goods which may
be used to attract money"; "A development model (community based
development): discovering strengths/assets, assigning group leaders, developing
the strategy (the main points) and managing the development plan"; "The owner
is a pioneer - he starts projects and when things start to go well he withdraws




\section{GEOGRAPHY UNIVERSITY STUDENTS' AWARENESS OF THEIR OWN LEARNING PROCESS DURING THE 2013 NEUBRANDENBURG ...}

and initiates something else"; "This park is a brave project of some very brave people"; "In Germany, many things (e.g. the creation of a national park) are decided at the state level, not at the federal state one"; "I learnt that one may conduct a survey even in a German village"; "When you build new buildings you have to contribute to the nature protection fund to compensate the change that you made in nature"; "Today I've learnt that we cannot rely only on wood, it's just part of the solution ... we must change our way of thinking and action; We should focus on energy efficiency - lower consumption ... if you look far into the future, you can reach far";

C3 - "I felt that his speech was less for us, the students, but rather for the locals"; "Fascinated by the results achieved by the inhabitants' associations"; "Off the topic, this content is not for me"; "Interested and enthusiastic"; "Satisfied with the success of the IP and that the local authorities were content";

D - "notes, photos, personal memory (memories)";

DCIV - "When the school closes in a village, any reason to live there vanishes; the school is a necessity"; identity as a resource - "something to do with tradition, something sustainable would make the place more attractive. Twothirds of the residents were not born here, but immigrants from Poland, the Czech Republic, etc."; "I discovered a new way to solve problems, a new mentality"; quotations within the journal: "Nothing is more important than practice, theory is the highest point of practice" or "The learning process is always important, not the product of learning";

RIV - "The Mill's Channel in Cluj-Napoca could be arranged as park (small chances)"; "The age structure in this district is a very good illustration of the impact of policy changes"; "Criteria for positioning wind turbines overlaid with the optimal localisation map"; "Professors feel very relaxed in front of the public. Even if they make mistakes, they ignore them and recover easily"; "A research model for many Romanian villages and beyond"; "Another development model that started from a dream"; "The Germans put great emphasis on the distance to the nearest market or school (indicated in minutes) and make suggestive maps with this indicator, allowing modelling: what happens if we close a school";

F - "I was praised for how I presented the results of my group."

Student 5 wrote reports on each day, on the basis of his notes, describing activities and their climaxes. He planned beforehand writing those reports (as he mentioned in his notes). These contained information organised in tables (Table 2) and also regular text and drawings.

Table 2. Reports for each day (Student 5)

\begin{tabular}{|l|l|l|}
\hline What have I learnt today? & How have I learnt it? & How have I felt? \\
\hline At the Centre for & - experimentation - I & - very well, joyful, happy, \\
Renewable Energy, we & have tested different & curious, accomplished. I \\
have had the opportunity & types of wind energy & have happily and actively \\
to test (touch, smell or & generators - the most & participated at all \\
see) all forms of possible & efficient ones for the & \\
\hline
\end{tabular}




\begin{tabular}{|l|l|l|}
\hline renewable energy. & $\begin{array}{l}\text { low wind power of the } \\
\text { local winds. }\end{array}$ & $\begin{array}{l}\text { activities. } \\
\text { We have obtained } \\
\text { information about possible } \\
\text { forms of energy applicable } \\
\text { in Lassan. }\end{array}$ \\
$\begin{array}{l}\text { I have learnt the city } \\
\text { development issues of } \\
\text { the church tower of } \\
\text { Neusterlitz. } \\
\text { presentation of the Múritz } \\
\text {-walk - in the National } \\
\text { Park. }\end{array}$ & $\begin{array}{l}\text { National Park. } \\
\text { Optimist, curious (at the } \\
\text { presentation of the case } \\
\text { studies), at the end bored } \\
\text { by so many presentations. } \\
\text { has captivated me) } \\
\text { Müritz National Park }\end{array}$ & $\begin{array}{l}\text { Satisfied due to the } \\
\text { quality of the information. }\end{array}$ \\
\hline
\end{tabular}

\section{2) Teaching methods, learning products and how students felt}

The results of our research on the learning journals include findings related to (a) the teaching methods facilitating their learning; (b) the products they realised as proof that their initial objectives and targets were accomplished and (c) how they felt during the process.

\section{(a) The teaching methods facilitating their learning}

- Students reflected on the professors' teaching methods: "In this journal, I should mention all the methods that professors used during the activities, but as I noticed after two days, there was no use to present them one by one because all professors used the same methods" (Student 4); "Qualitative methods are easier for students who do not know the researched region" (Student 5); "The cartographical methods and the explanatory drawing are useful for qualitative research and for group projects" (Student 5 referring to teaching methods within the groups of students); without mentioning their usefulness, only their use by professors: "The analysis of statistical social and demographical data. The analysis, the prospective method" (Student 5); "Lecture without PPP. Interesting discourse" (Student 5); "The professors used the following methods: the field trip, discussions with the local authorities, giving examples, getting into contact with the locals, etc." (Student 5);

- Lectures - more or less efficient. Related to PowerPoint presentations, students wrote that - "those did not help me learn much, but the second week was more interesting and the learning methods were 

PROCESS DURING THE 2013 NEUBRANDENBURG ...

efficient because my work group included smart and open-minded people" (Student 2). Nevertheless, Student 3 considered foreign professors' and unfamiliar professors' lectures as a positive factor for learning: "And I like to listen to strangers' lectures, I mean not to my professors', but other professors' or experts' in territorial planning. I tend to learn more if I don't know the voice". For learning, it was important how they presented the information in a PPP: "I learnt new things about Neubrandenburg by means of PPP, especially due to tables and charts" (Student 3). Student 7 wrote directly in English: "I think that some of the presentations were boring because the professors were focusing too much on their speech and PPPs and they don't care about the reactions of the audience and their presentations are a bit dry. On the other hand, the free discussion was very interesting and a lot of fun and I managed to learn a lot"; "very difficult lecture in English. The focus was not on solutions" (Student 5); "Lengthy presentation" (Student 5) or "Humorous, absorbing presentation, I felt good and had no emotions" (Student 5) or "he had an absorbing discourse and the public paid attention" (Student 8);

- Appreciation of group work and of interactive approaches. Students learnt to be indulgent (Student 3: "I learnt to accept the others' ideas even if those ideas did not coincide with mine"); "I may say that I gained a lot due to the summer school, I learnt a lot about group work, about other cultures and nations, and one cannot write in a journal how beautiful were the moments I lived with the new friends, one has to live them" (Student 4); "I like that we have an architect in our group. His perception of things in Lassan is interesting" (Student 3). Still there was certain bedevil because of unequal involvement of the group members in solving tasks (Student 3);

- Concrete ideas to real situations - not theory! "The most important thing was field work that in fact was a kind of group brainstorming with students from all participant countries" (Student 4); "I enjoyed very much this kind of studying and working that we have here because it is not about theory, it is more concrete, more practical, and I think more useful" (Student 11);

- Impulses for reflecting on the approached themes: "The inhabitants are looking for their identity, it is there, but they don't capitalise it enough for strengthening the traditions and customs in this area" (Student 6);

- What they learnt from the complementary programme to the scientific activities. Student 3 and Student 12 made observations about the city tour from the perspective of somebody who studied that topic at the Geography of Tourism specialisation during their university studies: "The guiding was sometimes too complicated. If I were a regular tourist, not a student, I would say that I paid the guided tour and got nothing because I did not see what I wanted. But I learnt a very important thing: the guide 
has to present only informative things, strictly on the respective topic. I learnt this because I participated. This will be useful for me if I had to be a guide sometime" (Student 3 ).

(b) The products they realised as proof that their initial objectives and targets were accomplished

The products they realised as proof that their initial objectives and targets were accomplished were in the form of notes (tables appeared in the journals of several students: such as that of Student 2 and of Student 5), posters (Figures 2-5), and photos (Figure 6). The students from Romania created a common folder containing all the photos they took during the summer school), maps, plans, drawings, flyers, etc. To sum up, the journals included proof of individual and group work: notes, posters, photos, maps, and plans. For instance, Student 10 had the task to realise a photo journal in her working group.

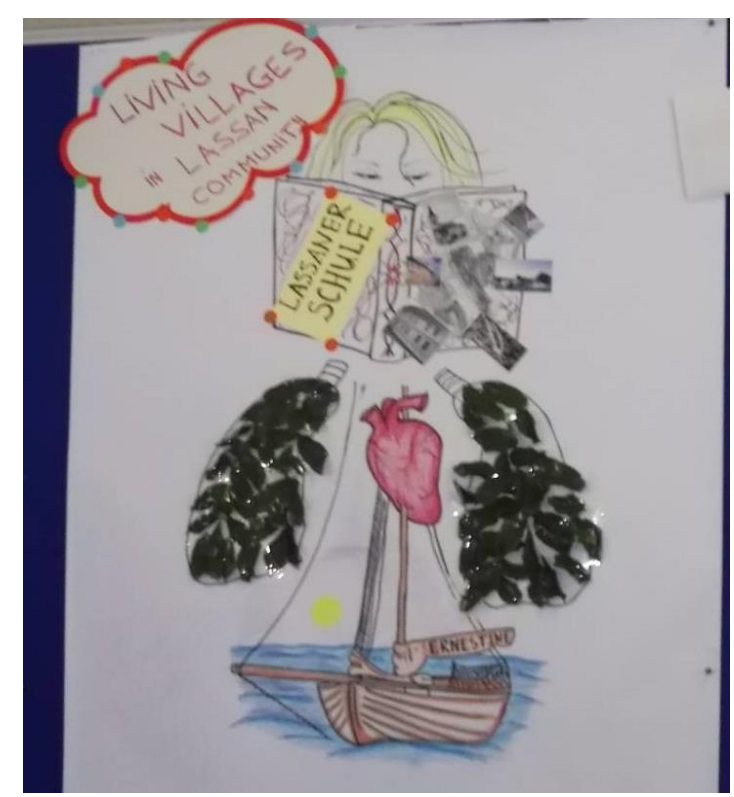

Fig. 2. Poster created by Group 8: "Living villages"

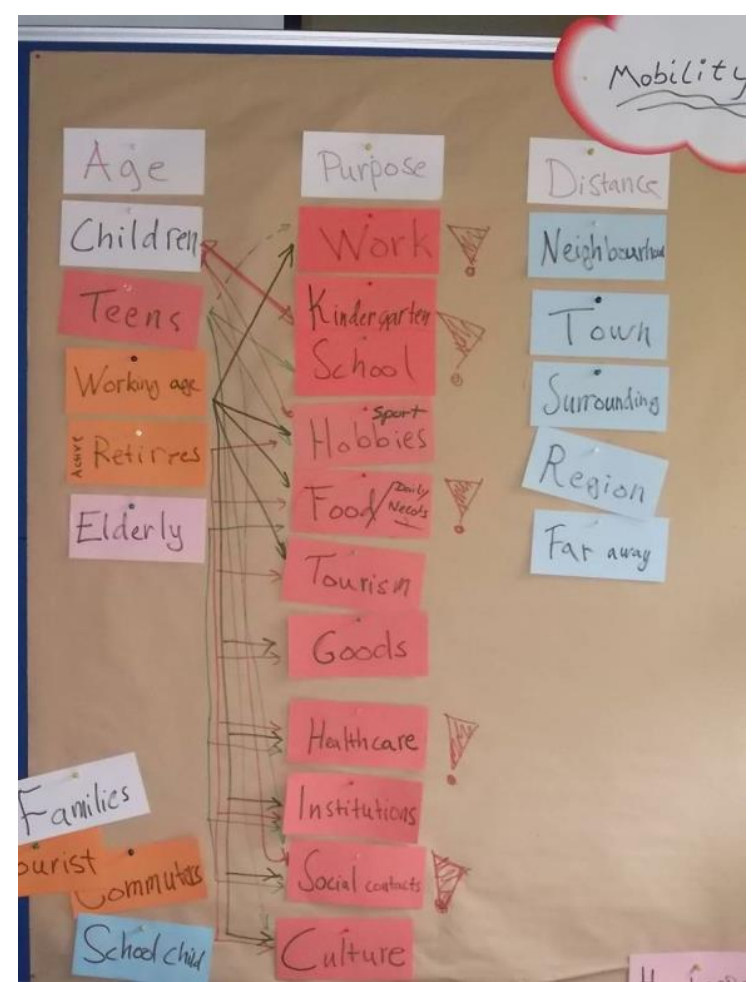

Fig. 3. Work in progress for the group on mobility solutions 


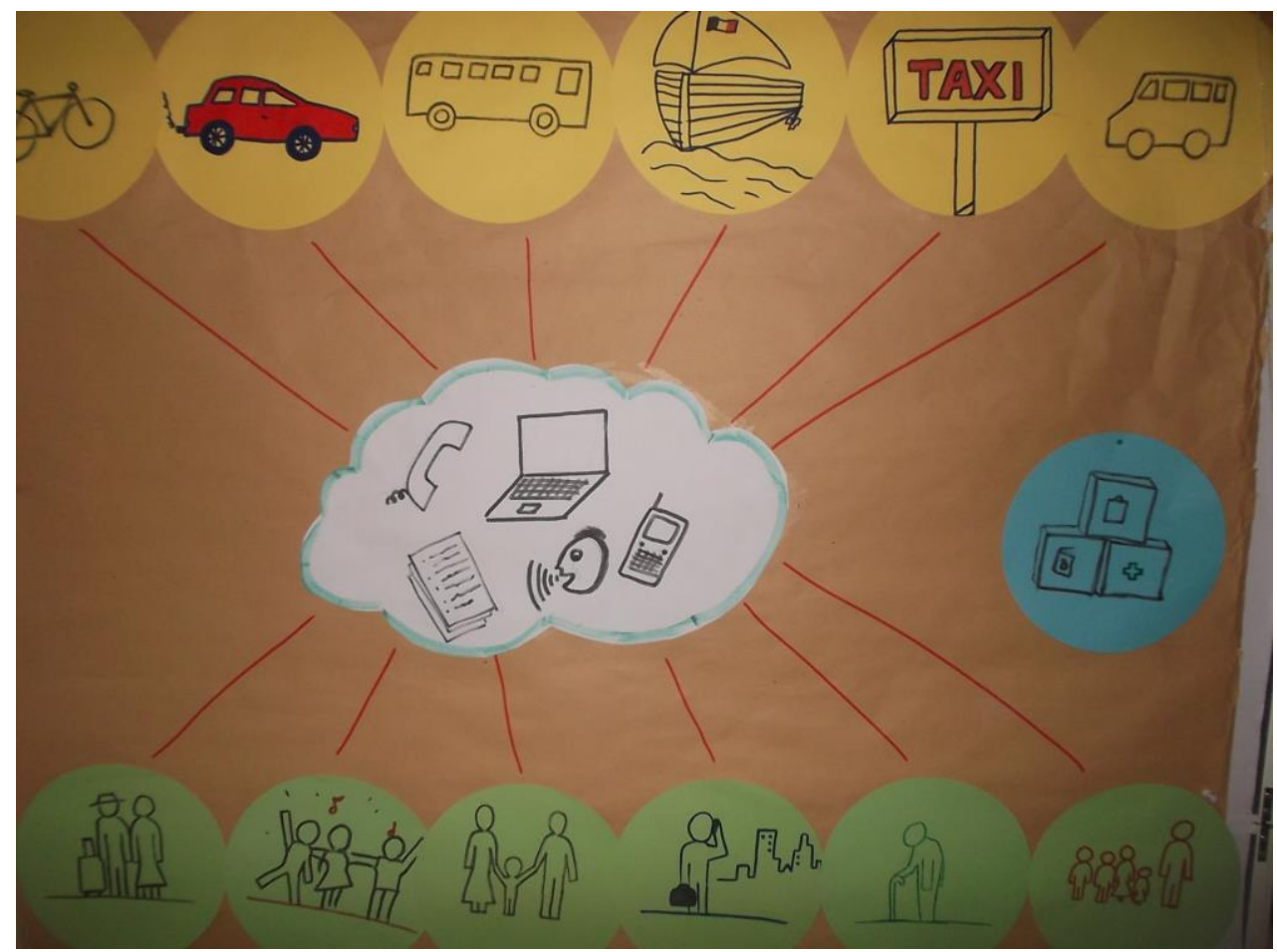

Fig. 4. Poster created by the group working on "Mobility in Lassan"

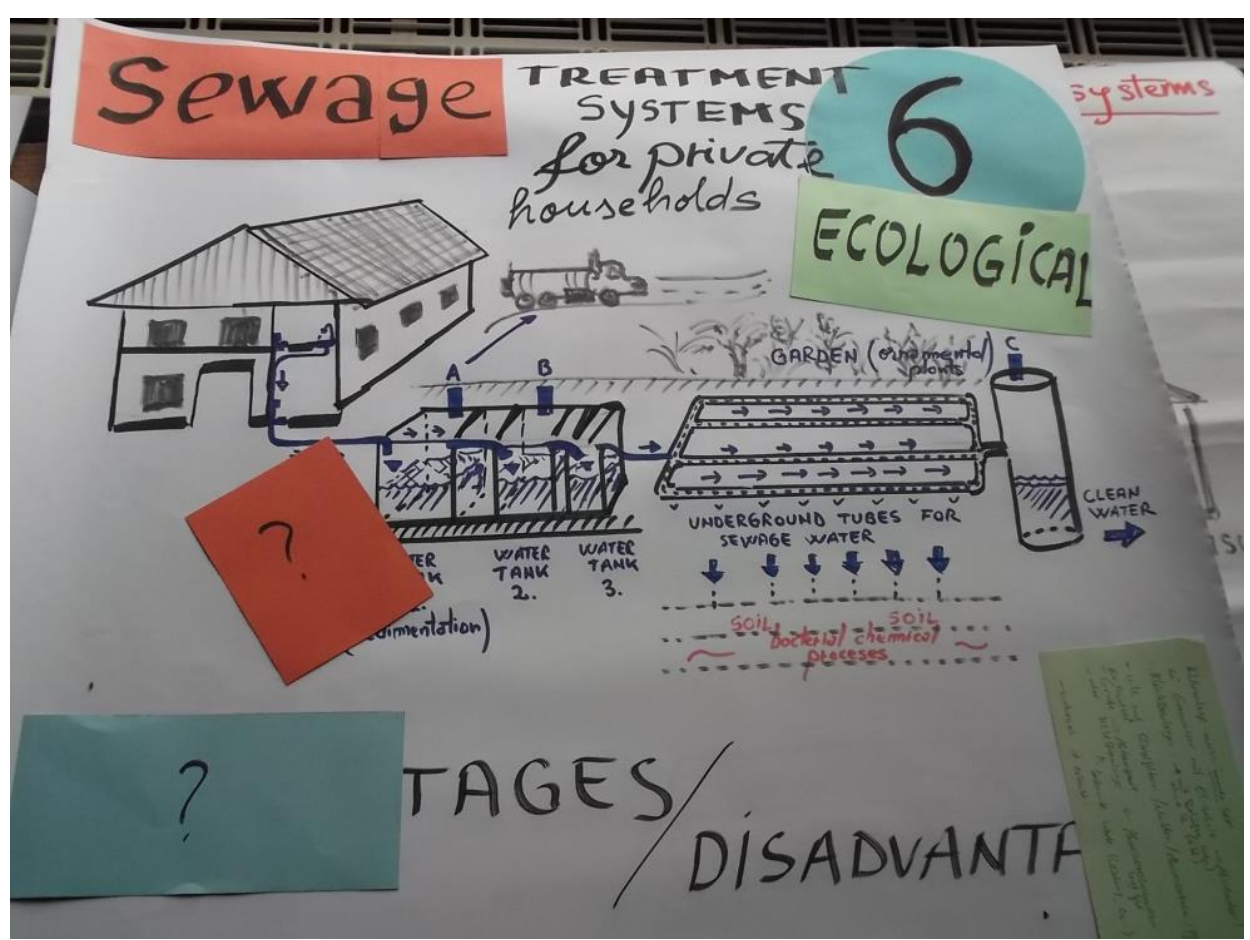

Fig. 5. Poster created by Group 6: "Water and Sewage systems" 


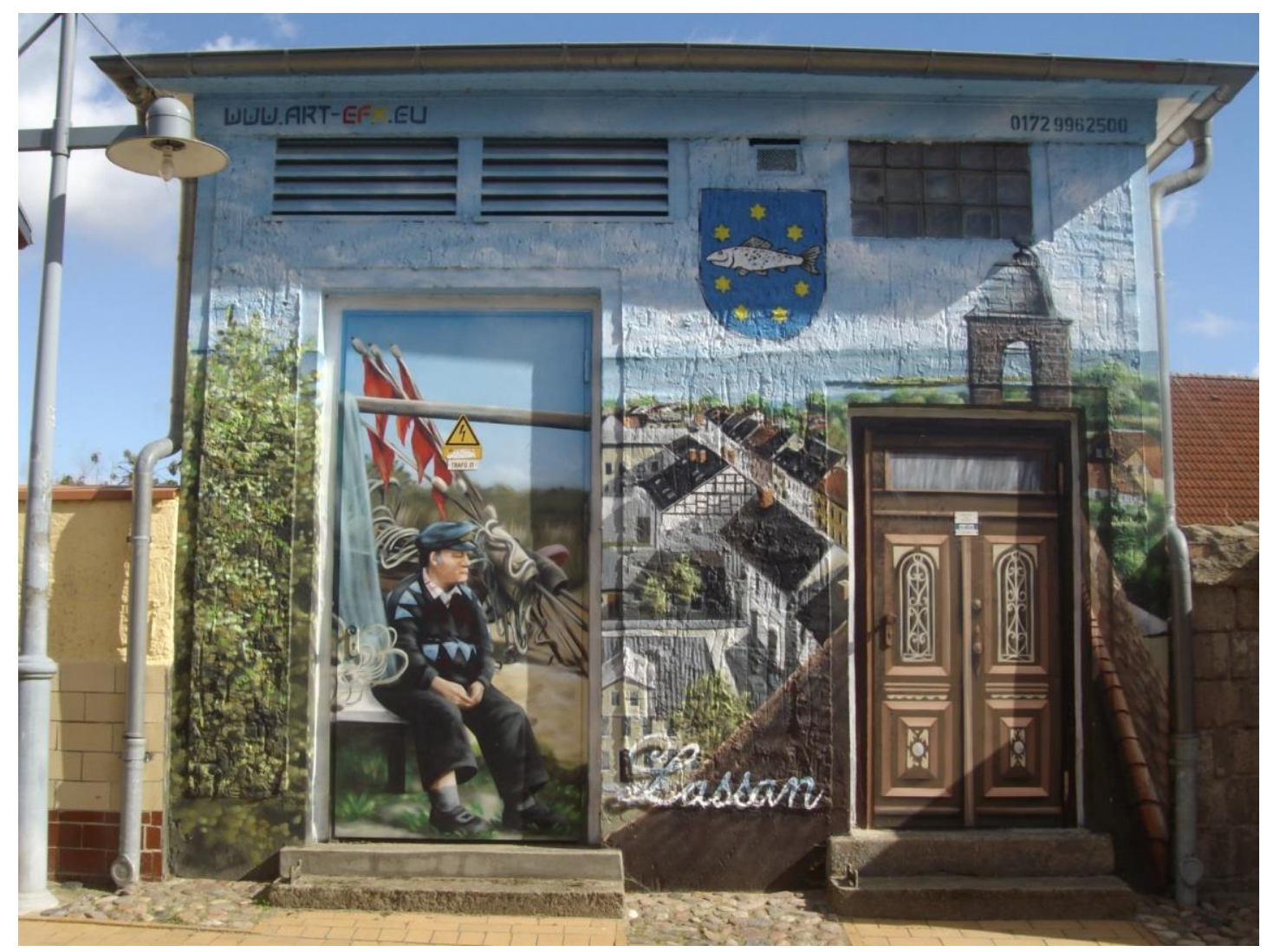

Fig. 6. Identity elements representation of Lassan community (Student 10)

(c) How they felt during the process

- Impressions about the circumstances (weather, accommodation, meals): "Today wasn't a good day because of the bad weather" (Student 7); "Because of the rain, nobody was patient during the city tour. Nevertheless, we learnt about the harbour and the town church" (Student 8).

The personal impressions about those circumstances influenced very much students' state of mind: "I like very much the way the summer school is organised. I like that every activity is well planned and the plan is observed even if we don't have so much free time. I appreciate the punctuality and the fact that somebody tells us what we are going to do next and we don't have to check the programme. What was surprising for me is the fact that we came in Germany, a well-developed country, and we will have to sleep in tents" (Student 11). Moreover, their health influenced their concentration and learning process.

- Impressions about certain people (i.e. appreciation) and presentations (i.e. interesting, boring): "The most interesting person was Johannes and his speeches were interesting, too" (Student 8); 


\section{GEOGRAPHY UNIVERSITY STUDENTS' AWARENESS OF THEIR OWN LEARNING PROCESS DURING THE 2013 NEUBRANDENBURG ...}

- Curiosity or boredom - depending on the topic or length of presentations: "with an absorbing speech and the public paid it a lot of attention" (Student 8); "The lectures were interesting... and they were closer to my field of interest" (Student 8);

- Satisfaction about/disappointment with their work group: "Related to new contacts and socialising, even if we met new people they were not interested to discuss ideas. This is also because we all study very different fields" (Student 8); "In group no. 5 (water + sewage) I had the idea of a wind pump for sewage water and gravity pipes (a functional system that needs no electricity or other supplementary monthly costs). They rejected my idea" (Student 5);

- Identifying certain competition among the participating countries and among the work groups: "I felt very good when they applauded us as the Romanians" (Student 3); "At the morning presentation, I felt that the other groups worked better than us. Eventually, our group turned out well, too" (Student 3);

- Positive feelings after in depth understanding of a certain subject: "Well done presentation!" (Student 9);

- The feeling that they succeeded, especially when the other appreciated their performance: "Self-assessment criteria: I managed to explain by myself the sketch Regions in a downward spiral; I learnt about the time bank. I managed to compare certain case studies with the situations I knew" (Student 5); "I spoke in English with professor XY about the town church, making a comparison with the Black Church in Braşov (this talk encouraged me much about my English language skills)" (Student 5);

- Other notes about participants' feelings: "Impressed; interested; curios; sad; I agreed; that took me out of boredom; I thought a lot" (Student 2); "I felt tired, but interested and happy" (Student 6); including a drawing as a final report with the student's "state of mind" and "new knowledge" - one student used the drawing to express his conclusions Figure 7); "very tired and frozen (+ hungry)" (Student 5); "I was incredibly content that I am here to see all these" (Student 5); interested or not, according to student's knowledge, specialisation or the answer to the question "what use do I have for this?"; expectations related to the accommodation (Tollensee - "I will not complain anymore about the conditions" (after the guided tour) (Student 11); the feeling of being successful appeared also after the others' appreciation of their group work: "I learnt that it was possible to make a survey in a German village, too" (Student 11); "We saw the Baltic Sea and discovered the touristic potential of this place. It was the best day of the summer school" (Student 7); "Yes, my expectations from the summer school were satisfied" (Student 1); "I was very proud of Transylvania and my professors" (Student 10).

Students also expressed their learning through general observations and through certain quotations (sayings) they liked: "I learnt that people's needs and lack of resources lead to compulsory development" (Student 5); 
"together we are strong" (Student 5); "What is always important is the learning process, not the learning product" (Student 11); "The key is communication!" (Student 6); "Things happen: by chance, by accident, impulses from outside, phantasy and ideas, courage to strike new paths, collaboration and networks, public awareness, political will" (Student 6 and Student 12 mentioned this last one).

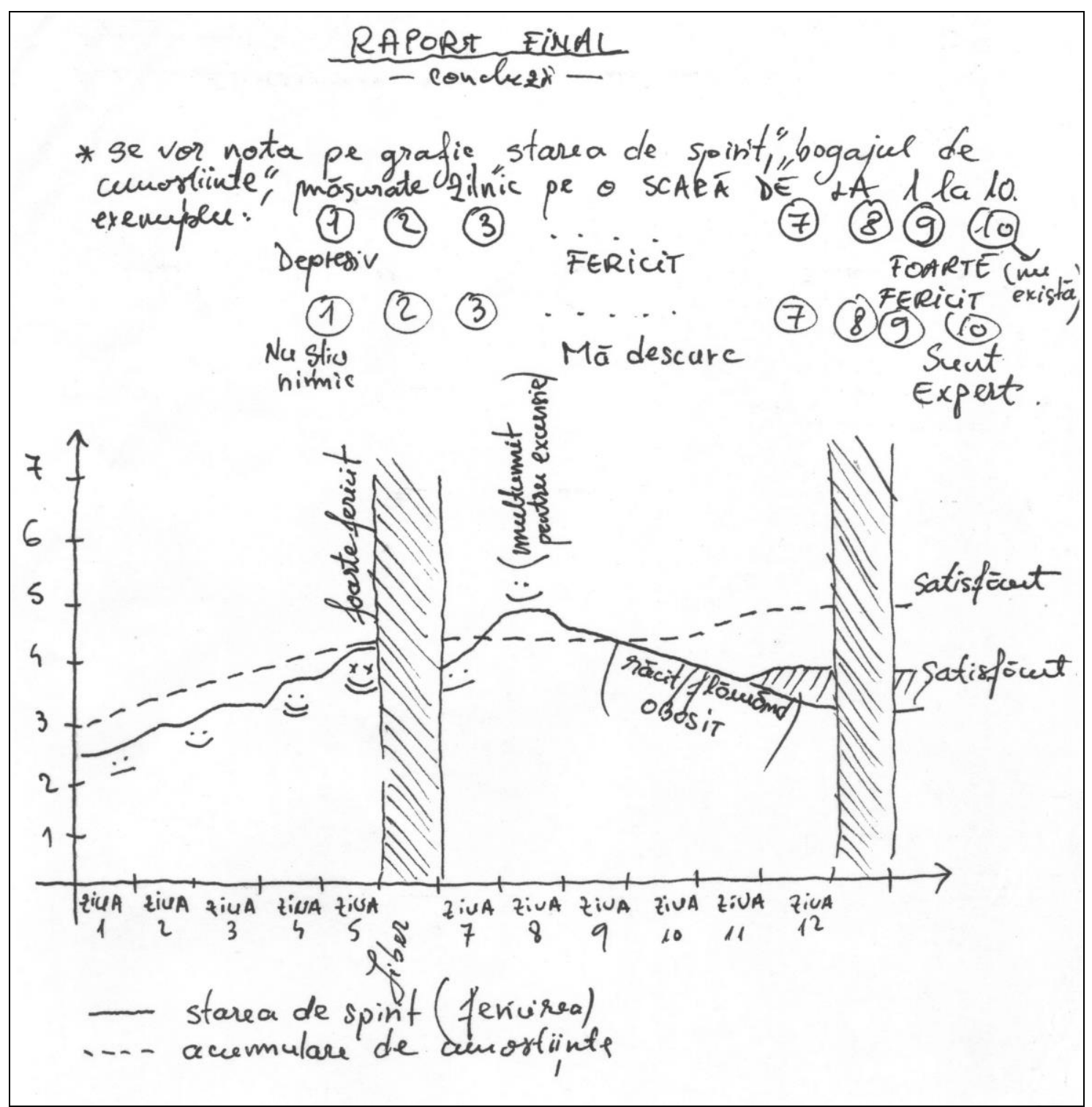

Fig. 7. Conclusions expressed through drawing (author: Maroşi Zoltan) (This student used the words: happiness, sadness, satisfied or not, not knowing anything and being an expert on a certain topic. He used two indicators that he measured on a scale from 1 to 10 , with 10 the maximum that could be obtained: his state of mind and his knowledge of a certain topic) 


\section{GEOGRAPHY UNIVERSITY STUDENTS' AWARENESS OF THEIR OWN LEARNING PROCESS DURING THE 2013 NEUBRANDENBURG ...}

These journals included also notes on the approached topics: some notes were reflections on the approached topics (Student 5 identified the strengths and weaknesses of Lassan town in report no. 3); satisfied/unsatisfied expectations (Student 3 - "my group members don't want or don't consider necessary the use of graphical design softs"); details about personal interest subjects, even if their topic did not relate to the summer school theme (e.g. Student 5 wrote about the Fachwerk architecture); "Neither did I know much about this topic, nor did it attract me much" - the topic was social cohesion and the student was in the group that researched rural life, and this meant that the respective student did not make the connection between theory and practice; "This subject is incomprehensible. I don't have the necessary training" (Student 9).

The learning journal was also a place where students expressed their: dissatisfactions and observations ("Not even one territorial arrangement plan from another country did I see" - Student 5 or "There is a basis for all the things required from small settlements, but there is no centre for their management and promotion" - Student 5; students were aware of the development differences between Romania and Germany: "My first impression about Lassan was that the settlement was pleasant and from an Eastern European perspective its situation doesn't seem so bad as I expected" (Student 12); satisfactions ("After the meeting with the official representatives of Lassan I was surprised to observe that they are very open minded and they want to receive ideas from foreign students. I also appreciate very much their readiness to answer all the questions that the students had and to offer precious information about everything in their district" - Student 11); they wrote was new ("For the first time I participated at a voting session in PowerPoint" - Student 5); "I have heard about the time bank for the first time in my life" - Student 5); they asked themselves questions and put down what they wanted to ask the others ("Where are the fresh water resources of the village? And also I want to ask if there are any environmental initiatives to use rain water in some home activities" - Student 5).

Students 6 and 9 wrote what the Unidorf strategy, that they took part at, meant: "partnership between universities and certain communities, thus trying to find solutions for local development" (Student 6) and "knowledge transfer, impulses for development" (Student 9). Student 11 wrote: "UniDorf - University Village. Since 2010 four UniDorf projects have been functioning in this district". This proves that they were aware of the role they had and that is the conclusion that we might draw from one of the students' assertions. For instance, Student 11 felt responsible for the results of the summer school and took his role very seriously: "Today was the first day in Lassan. Here we have to face two big challenges: one to sleep in the tents (some of us never slept in tents before). The second challenge is to bring some ideas to Lassan community". 
The journals included notes on intercultural interaction and on mutual acquaintance: "I noticed that Germans complained, but with a positive purpose because it motivated them to keep on searching for solutions" (Student 12); "We have seen how unknown is Transylvania for the other participants" (Student 2); one regret was expressed: "there was just one party that all participants attended" (Student 2); "A very important aspect was multiculturalism and intercultural communication between nations, especially at the International Evening" (Student 4); "... I did not like the Bulgarian food, instead I enjoyed the German drink" (Student 2); "The International Evening was interesting primarily because it was not so official and we learnt many new things about the members of the other universities" (Student 3); "I realised that the Germans are not like us: we try to give everything, the most and the best so that everything is great" (Student 3); "The mentality of people in this area is quite different from Romania, but they also encounter problems in adapting to current situations" (Student 6); "The thing that emerged from the presentation of the Bulgarians was the illegal cheese" (Student 2). Student 5 also mentioned the Bulgarian case study on the "green cheese (illegal activity)"; "Bulgaria is the most pessimistic country in the world" - statement in Bulgarians' presentation that Student 6 put down; "I learnt that in Germany problems are solved at the level of associations" (Student 6).

The students also mentioned ideas to apply at home or in locations of momentary or long-term interest for them: "The city of Waren is very nice, as the new centre of Braşov. In the future, I can develop my idea of creating such a museum at home, because it works well without any state aid" (Student 3); "The channel built in the past is totally different from the modern ones, it is self-sufficient (the Mill's Channel in Cluj could look like this)" (Student 11); "This idea can also be applied to Lassan" (Student 8).

In all journals, we discovered that the electronic voting system impressed many of the participants: "The opening ceremony - The vote impressed me the most; it was fun, new, and interactive" (Student 12) and the bikes, new friends, and the song "Boom City", these all were sources of joy for many students.

Despite its downside, which was the extra workload for both students and professors, requiring more time commitment, we noticed that the learning journal really encouraged students' independent thinking. They became more actively engaged and thus more autonomous learners. They were also more active learners and they were able to see how their understanding changed during the summer school activities. Moreover, we got invaluable feedback on how our students coped with diverse tasks and situations. 


\section{GEOGRAPHY UNIVERSITY STUDENTS' AWARENESS OF THEIR OWN LEARNING PROCESS DURING THE 2013 NEUBRANDENBURG ...}

\section{CONCLUSIONS}

According to the findings, we concluded that due to the beneficial combination of theory and field work in an international, partly guided interdisciplinary working environment, the summer school activities promoted the key competences for successful education and facilitated added value to the education of Geography students:

- basic competences in science: the summer school provided insight into the geography, the history, the society, and into the economics of the researched regions, also dismounting preconceptions. The event supplied participants with complementary materials, web platforms for information and exchange, with case studies and with best practice examples;

- learning to learn and sense of initiative and entrepreneurship: the summer school offered the frame for an enriching exchange of ideas, to acquire knowledge, to develop team work, analytical and critical thinking, etc. Working together with the specialists in different fields produced and added up complex and complementary insights on the same topic. The activity not only offered insight in the working environment, but also underlined the various points of view involved and encouraged the critical analysis of the situation;

- social and civic competences: working and living together with participants from other four countries provided the frame for intercultural exchange. Moreover, this supported further co-operation between the organising institutions, creating networks for the participant students and for the young researchers;

- communication in foreign languages: the international format of the summer school, the mixed working groups and the setting in a foreign country animated the participants to apply and improve their language competences.

Regarding the efficiency of the learning journals as educational tools, the findings showed a certain reflection of the students about their learning process; results demonstrated how writing the journal raised their awareness about personal educational needs/challenges, and also about personal abilities and accomplishments/qualifications. The learning journals mentioned situations in which particular components of competences were consciously applied, trained, or acquired.

The learning journal also offered the frame for a critical assessment of the applied educational methods, which could be a useful tool for both teachers and professors. Personal impressions about the organisational frame were a valuable feedback for the organisers of the event. We concluded that the learning journal was successful in empowering our students and making them aware of their learning. 
A general conclusion is that such summer schools provide enriching experiences and training on all levels (i.e. personal, educational, and professional).

\section{Acknowledgement}

The authors thank Professor Maria Eliza Dulamă, Babeş-Bolyai University, Romania, for support and suggestions when creating the design of this research, before the summer school started, and for her feedback when we presented the contents of this contribution at the international conference "Contemporary Trends in Teaching and Learning Geography", in 2013, in Cluj-Napoca, Romania.

\section{References}

A Summary of EU Legislation Establishing the European Framework of Key Competences, Retrieved July 15 2013, from http://europa.eu/legislation_summaries/education_training_youth/lifelong_lea rning/c11090_en.htm

Breitbart, M. (2012). Participatory Research Methods. In Clifford N., French S., Valentine G. (eds.), Key Methods in Geography, $2^{\text {nd }}$ edition (pp. 141-156). London: Sage.

Brien, R. (1997). Science cognitive \& formation. Montreal: Presses de I'Université de Québec.

Brochure: Key Competences for Lifelong Learning - European Reference Framework (an annex of a Recommendation of the European Parliament and of the Council of 18 December 2006 on key competences for lifelong learning), Retrieved July 15 2013, from http://ec.europa.eu/dgs/education_culture/publ/pdf/IIlearning/keycomp_en.pdf

Cantrell, R.J., Fusaro, J.A., \& Dougherty, E.A. (2000). Exploring the Effectiveness of Journal Writing on Learning Social Studies: A Comparative Study. Reading Psychology, 21(1), 1-11.

Carroll, M. (1994). Journal Writing as a Learning and Research Tool in the Adult Classroom. TESOL Journal, 4(1), 19-22.

Charlesworth, S.M., \& Foster, I.D.L. (1996). 'Water and Environmental Systems': Achieving Student Centred Learning Objectives with an Undergraduate Journal. Journal of Geography in Higher Education, 20(1), 45-54.

Connor-Greene, P.A. (2000). Making Connections: Evaluating the Effectiveness of 


\section{GEOGRAPHY UNIVERSITY STUDENTS' AWARENESS OF THEIR OWN LEARNING PROCESS DURING THE 2013 NEUBRANDENBURG ...}

Journal Writing. Enhancing Student Learning. Teaching of Psychology, 27(1), 44-46.

Cook, I. (2000). 'Nothing Can Ever Be the Case of "Us" and "Them" Again': Exploring the Politics of Difference Through Border Pedagogy and Student Journal Writing. Journal of Geography in Higher Education, 24(1), 13-27.

Croxton, C.A., \& Berger, R.C. (2001). Journal Writing: Does It Promote Long Term Retention of Course Concepts? Retrieved 8 August 2014, from http://www.ntlf.com/html/sf/journal.htm

Dart, B.C., Boulton-Lewis, G.M., Brlwolee, J.M., \& Mccrindle, A.R. (1998). Change in Knowledge of Learning and Teaching through Journal Writing. Research Papers in Education: Policy and Practice, 13(3), 291-318.

Dulamă, M.E. (2010). Fundamente despre competenţe. Cluj-Napoca: Editura Presa Universitară Clujeană.

Fouberg, E.H. (2000). Concept Learning through Writing for Learning: Using Journals in an Introductory Geography Course. Journal of Geography, 99(5), 196-206.

Haigh, M. (2001). Constructing Gaia: Using Journals to Foster Reflective Learning. Journal of Geography in Higher Education, 25(2), 167-189.

Havadi-Nagy, K.X., \& Ilovan, O.R. (2013). International Summer Schools in a Knowledge-Based Society and University. Acta et Commentationes. Ştiinţe ale Educaţiei. Revistă ştiinţifică, 2(3), 126-133.

Hedlund, D.E., Furst, T.C. \& Foley, K.T. (1989). A Dialogue with Self: The Journal as an Educational Tool. Journal of Humanistic Education and Development, $27,105-113$.

http://sommerschuleubb.wordpress.com/, Retrieved July 72013.

https://goeast.daad.de/de/23285/index.htmlhttps://eu.daad.de/erasmus/managem ent/intensivprogramme/de/11627-intensivprogramme/, Retrieved July 7, 2013.

Hyers, A.D. (2001). Predictable Achievement Patterns for Student Journals in Introductory Earth Science Courses. Journal of Geography in Higher Education, 25(1), 53-66.

Langer, A.M. (2002). Reflecting on Practice: Using Learning Journals in Higher and Continuing Education. Teaching in Higher Education, 7(3), 337-351.

McCrindle, R.A., \& Christensen, A.C. (1995). The Impact of Learning Journals on Metacognitive and Cognitive Processes and Learning Performance. Learning and Instruction, 5(2), 167-185.

Morrison, K. (1996). Developing Reflective Practice in Higher Degree Students through a Learning Journal. Studies in Higher Education, 21(3), 317-332.

O'Rourke, R. (1998). The Learning Journal: From Chaos to Coherence. Assessment \& Evaluation in Higher Education, 23(4), 403-413.

Park, C. (2003). Engaging Students in the Learning Process: The Learning Journal. Journal of Geography in Higher Education, 27(2), 183-199.

Programme - International Summer School "Shaping Regions in Transition: Small Town and Rural Development Challenged by Socio-Demographic Change, 
16th-28th of September, 2013". Retrieved 1 August 2013, from http://www.hs-nb.de/uploads/media/Programme_02.pdf

Recommendation 2006/962/EC of the European Parliament and of the Council of 18 December 2006 on key competences for lifelong learning, in Official Journal L 394 of 30.12.2006. Retrieved 15 July 2013, from http://eurlex.europa.eu/LexUriServ/LexUriServ.do?uri=OJ:L:2006:394:0010:0018:EN:PDF

Shaping Regions in Transition: Small Town and Rural Development Challenged by Socio-Demographic Change, 16th-28th of September 2013. Retrieved 1 August 2013, from http://www.hs-nb.de/start/international/internationalsummer-school/

Stanesco, J.D. (1991). The Personal Journal as a Learning and Evaluative Tool in Geology Field-Trip Courses. Journal of Geological Education, 39(3), 204-205.

Sublett, M.D. (1991). Incorporating Student Logbooks into Geography Classes. Journal of Geography, 90(2), 50-53.

Thorpe, K. (2004). Reflective Learning Journals: From Concept to Practice. Reflective Practice, 5(3), 327-343.

Wagner, Z.M. (1999). Using Student Journals for Course Evaluation. Assessment \& Evaluation in Higher Education, 24(3), 261-272.

Walden, P. (1988). A Learning Journal as a Tool to Promote Life Long Learning Skills. Feminist Teacher, 3(2), 14-17.

Yinger, R. (1985) Journal Writing as a Learning Tool. Volta Review, 87(5), 21-33. 